University of Nebraska - Lincoln

DigitalCommons@University of Nebraska - Lincoln

Agronomy \& Horticulture -- Faculty Publications

Agronomy and Horticulture Department

May 2008

\title{
Leaf area index simulation in soybean grown under near-optimal conditions
}

T. D. Setiyono

University of Nebraska-Lincoln, tsetiyono2@unl.edu

Albert Weiss

University of Nebraska-Lincoln, aweiss1@unl.edu

James E. Specht

University of Nebraska-Lincoln, jspecht1@unl.edu

Kenneth G. Cassman

University of Nebraska-Lincoln, kcassman1@unl.edu

A. Dobermann

University of Nebraska-Lincoln

Follow this and additional works at: https://digitalcommons.unl.edu/agronomyfacpub

Part of the Plant Sciences Commons

Setiyono, T. D.; Weiss, Albert; Specht, James E.; Cassman, Kenneth G.; and Dobermann, A., "Leaf area index simulation in soybean grown under near-optimal conditions" (2008). Agronomy \& Horticulture -Faculty Publications. 113.

https://digitalcommons.unl.edu/agronomyfacpub/113

This Article is brought to you for free and open access by the Agronomy and Horticulture Department at DigitalCommons@University of Nebraska - Lincoln. It has been accepted for inclusion in Agronomy \& Horticulture -Faculty Publications by an authorized administrator of DigitalCommons@University of Nebraska - Lincoln. 


\title{
Leaf area index simulation in soybean grown under near-optimal conditions
}

\author{
T. D. Setiyono ${ }^{1}$, A. Weiss ${ }^{2}$, J. E. Specht ${ }^{1}$, K. G. Cassman ${ }^{1}$, and A. Dobermann ${ }^{1,3}$ \\ ${ }^{1}$ Department of Agronomy and Horticulture, University of Nebraska-Lincoln, P.O. Box 830915, Lincoln, NE 68583-0915, USA \\ ${ }^{2}$ School of Natural Resources, University of Nebraska-Lincoln, P.O. Box 830728, Lincoln, NE 68583-0728, USA \\ ${ }^{3}$ International Rice Research Institute, DAPO Box 7777, Metro Manila, Philippines \\ Corresponding author: T. D. Setiyono, tel. 402 472-1623, fax 402 472-7904, email tsetiyono2@unl.edu
}

\begin{abstract}
Different approaches have been used to simulate leaf area index (LAI) in soybean (Glycine max L. Merr). Many of these approaches require genotype-specific calibration procedures. Studies modeling LAI dynamics under optimal growth conditions with yields close to the yield potential of soybean have remained scarce. A sink-driven approach was developed and evaluated for LAI simulation in soybean under near-optimal environments. The rate of change in expanding leaf area was simulated using the first derivative of a logistic function accounting for plant population density, air temperature, and water deficit. The rate of change in senescing leaf area was also simulated using the first derivative of a logistic function, assuming monocarpic senescence that began at the flowering stage (R1). Phenology was simulated as a function of temperature and photoperiod. Data for model development and evaluation were obtained from irrigated field experiments conducted at two locations in Nebraska, where agronomic management was optimized to achieve growth at a near yield potential level. LAI simulation with the proposed model had average RMSE of $0.52 \mathrm{~m}^{2} \mathrm{~m}^{-2}$ for independent data at the two locations. The proposed model has minimum input requirements. Interactions between leaf growth and source-driven processes can be incorporated in the future, while maintaining the basic physiological assumptions underlining leaf expansion and senescence.
\end{abstract}

Keywords: soybean, Glycine max, leaf area index, simulation, crop modeling, logistic function, beta function, water balance

\section{Introduction}

Soybean (Glycine max L.) is an important source of protein and oil for human and animal consumption (Reicosky and Heatherly, 1990), which is one reason for the early interest in simulating soybean growth, development, and yield (Acock and Trent, 1991; Curry et al., 1975; Wilkerson et al., 1983). Key stages in simulating soybean development are emergence, unifoliate (node of the 1st leaves), and trifoliate nodes (nodes of the 2nd leaf to the last leaf on the main stem), flowering (R1), full bloom (R2), beginning pod (R3), full pod (R4), beginning seed (R5), full seed (R6), and physiological maturity (R7) (Fehr and Caviness, 1977). Accurately simulating leaf area index (LAI) is necessary for the accurate simulation of biomass accumulation and transpiration. The opposite is also true, partitioning to the leaves to form new leaf area is influenced by biomass accumulation. A typical LAI pattern begins with a lag increase early in the season, followed by a rapid increase of LAI until a maximum value is reached, then a decline of LAI as leaves senesce and plants reaches physiological maturity. There have been several approaches to simulating LAI in soybean crop simulation models (Boote et al., 1998; Sinclair, 1986) or in generic crop models applicable to soybean (Boogard et al., 1998; Brisson et al., 2003; Robertson et al., 2002).

The conversion from dry matter to leaf area and vice versa is a process of iterative nature associated with the simulation of leaf growth. Because of this iterative nature, simulated leaf area is sensitive to initial LAI values (Brisson et al., 2006). Specific leaf area (SLA) is the ratio of one sided leaf area to the dry matter of the leaf $\left(\mathrm{cm}^{-2} \mathrm{~g}^{-1}\right)$ and is used to calculate the rate of change in leaf area based on the rate of change in leaf dry matter. SLA varies in different environments, developmental stages, and strata of leaves within the canopy (Gunn et al., 1999; Lieth et al., 1986; Lugg and Sinclair, 1979). The mechanism of such flexibility in SLA is still not known and thus the variable often becomes the source of uncertainty in models that rely on SLA in simulating LAI (Tardieu et al., 1999). Lugg and Sinclair (1979) showed that SLA of the uppermost fully expanded soybean leaf varied from $0.333 \mathrm{~cm}^{2} \mathrm{mg}^{-1}$ at $\mathrm{R} 1$ to $0.146 \mathrm{~cm}^{2} \mathrm{mg}^{-1}$ at R6. If an average SLA is assumed under such conditions, calculated LAI based on leaf dry matter and SLA is 64\% higher than the actual LAI at R6. Partitioning of dry matter in leaves between soluble versus structural carbohydrate is another uncertainty aspect dealing with SLA (Gunn et al., 1999). 
Carbon accumulation is not directly a mechanism of leaf expansion and thus SLA should not be regarded as model parameter but rather as an output (Tardieu et al., 1999).

In Sinclair (1986), SLA was only used in the net senescence phase. It indirectly influenced the partitioning of dry matter to the stem. A constant SLA of $0.250 \mathrm{~cm}^{2} \mathrm{mg}^{-1}$ was assumed for each increment of leaf area. The total above ground dry matter influenced the calculation of the nitrogen budget along with nitrogen fixation, which ultimately drives the amount of nitrogen available for leaves. The shortage in nitrogen under increasing demand, primarily as a result of seed growth, was the driving force of senescence. During the net expansion phase, LAI was simulated as a function of the plastochron index (the time interval between successive leaf primordia) and population density while plastochron index was driven by accumulation of thermal time since sowing.

LAI simulation in CROPGRO (Boote et al., 2003) was based on the rate of gain and loss of leaf area. The rate of gain and loss of leaf area was based on the conversion of leaf dry matter to area using SLA of the new leaf material and the whole plant SLA. The reduction in leaf dry weight was driven by senescence, insect damage, freeze injury, and $\mathrm{N}$ mobilization. Vegetative tissue growth was assumed to be limited by sink strength before a specified number of main stem leaves (VSINK) has appeared (at V5 stage). The calculations for partitioning of dry matter to the leaf differ before and after VSINK. As a result, the simulated LAI prior to VSINK was dependent on the rate of leaf area expansion under 'sink driven growth' while simulated LAI after VSINK was dependent on the partitioning of dry matter to the leaf, specific leaf area of the new leaf tissue, and total carbohydrate available for growth. The rate of leaf area expansion under 'sink driven growth' was a function of the cultivar-specific inputs and V-Stage. The fraction of dry matter partitioned to the leaf was determined based on V-Stage while SLA of the new leaf tissue was a function of cultivar- and species-specific inputs, temperature, photosynthetically active radiation (PAR), and water stress (Boote et al., 2003).

Simulation of LAI in the WOFOST-model (Supit and Van der Groot, 2003) involved classification of leaf tissue according to physiological age. Physiological age of leaf tissue was a function of maximum temperature $\left(35^{\circ} \mathrm{C}\right)$, base temperature $\left(7^{\circ} \mathrm{C}\right)$, and daily average temperature $\left({ }^{\circ} \mathrm{C}\right)$. The life span of leaf tissue was assumed to be 23 days at reference temperature $\left(25^{\circ} \mathrm{C}\right)$. The order of the leaf class (the leaf tissue produced during a daily time step) was from 1, 2, 3, $\ldots, n$, where 1 represented new leaf tissue and $n$ represented the oldest leaf tissue. Each day new leaf tissue was assigned as class 1 while the previous day's leaf tissue was designated as class $1+j$, where $j$ is the number of days since the leaf tissue was formed. LAI was simulated as the total area of leaves from all ages at a given time including leaf area at emergence. The area of each of the leaf classes was dependent on its dry matter $(L V)$ and specific leaf area (SLA). For new leaf tissue, there were intermediate relationships describing SLA and $L V$ allowing the area calculation to depend solely on the rate of change in leaf area $(G L A)$. GLA was calculated as minimum between sinkand source-limited leaf area expansions. Sink-limited green leaf area expansion was calculated recursively based on the maximum rate of leaf area expansion (a cultivar-specific parameter) and temperature. The recursive algorithm of sink-limited leaf area growth allowed simulated LAI to have an exponential shape. Source-limited leaf area expansion was dependent on SLA, the partitioning coefficient of total dry matter to leaf dry matter, and available dry matter for growth. Available dry matter for growth was dependent on the rate of photosynthesis and respiration. Reduction in leaf area was only possibly from leaf classes $>1$ and was driven by aging and the maximum effect of either water stress or high LAI (mutual shading). In WOFOST, SLA was thus used in the context of leaf age, avoiding uncertainties in SLA due to phenology (Gunn et al., 1999). Supit and Van der Groot (2003) described that sink-limited growth was valid until the sourcedriven LAI becomes limiting. Because of the exponential growth of sink-driven LAI (driven by the recursive algorithm), the sink-limited leaf area growth rate always becomes unreasonably high later in the growing season, causing the source-driven functions to become the determining factor for the end results of simulated LAI.

Brisson et al. (2003) provided flexible options for simulating LAI in the STICS-model. These options were standard, "more sophisticated" and a 5-parameter direct approach. In the standard option, LAI was directly calculated as the net balance between leaf growth and senescence. Net leaf growth rate from sowing to maximum LAI was driven by phenological stage using a logistic curve taking into account plant density, cultivar-specific inter-plant competition, and water and nitrogen stress indices. Determinate or indeterminate growth habits were distinguished from each other by the presence or absence of a plateau between maximum LAI to the onset of net senescence. From the onset of senescence LAI decreased as a linear function of cumulative thermal time and water stress was allowed to accelerate net senescence. In the more sophisticated option, simulation of LAI net expansion was the same as the standard option, but the net senescence was simulated based on a more direct relationship between cumulative thermal time and LAI, and also taking into account water and nitrogen stresses. The 5-parameter direct approach was used to generate LAI values independently from other simulation components of the model (Ripoche, 1999). When LAI data were available from sequential samplings, all five parameters could be optimized. In the standard and sophisticated options, cumulative thermal time toward the stage "end of juvenile phase" was a key parameter, which was suggested to coincide with the inflection point of LAI as a function of cumulative thermal time (Brisson et al., 2003).

Due to many source-feedback processes included as drivers, many commonly used approaches for simulating LAI require a substantial number of input parameters. For example, WOFOST simulation of LAI involves 82 input parameters (Boogard et al., 1998) of which 65 parameters are indirectly associated with LAI via dry matter accumulation and phenology components. Likewise, in CROPGRO 203 input parameters are used (Boote et al., 2003), 147 of which are indirectly associated with LAI via dry matter accumulation and phenology components. In some models, parameters with somewhat unclear biological meaning are used too, e.g., time of maximum LAI (Brisson $e t$ al., 2003; Sinclair, 1986), which are often cultivar-specific or have to be derived from model calibration to specific conditions. These input requirements may potentially limit the use of complex soybean simulation models for certain practical applications such as optimizing planting for maximizing yield potential (Bastidas et al., 2008) or making decisions on crop management. Likewise, evaluations of LAI simulations under growth conditions that approach soybean yield potential have remained limited.

The objective of this study was to develop and evaluate an approach for simulating LAI in soybean that recognizes key physiological and phenological processes using minimum input requirements. Key assumptions included the dominant autotrophic nature of leaf growth and the response of cell division and expansion to temperature and water deficit. A non-source-driven leaf area simulation was chosen in this study because source limitation was minimized by managing soybean at near optimum conditions. An important goal of this effort was to develop a model for practical application, one with reduced complexity and less cultivar-specific parameters. 
Table 1. Location, year, cultivar, phenology, row spacing, population density, maximum LAI and the use of these data for LAI simulation in Soybean

\begin{tabular}{|c|c|c|c|c|c|c|c|c|c|c|c|c|c|c|}
\hline \multirow[t]{2}{*}{ Location } & \multirow[t]{2}{*}{ Year } & \multirow{2}{*}{ Cultivar } & \multirow{2}{*}{$\begin{array}{c}\text { Stem } \\
\text { termination }\end{array}$} & \multirow{2}{*}{$\begin{array}{l}\text { Maturity } \\
\text { group }\end{array}$} & \multicolumn{2}{|c|}{ Emergence } & \multicolumn{2}{|l|}{ R1 } & \multicolumn{2}{|l|}{ R7 } & \multirow{2}{*}{$\begin{array}{l}\text { Row } \\
\text { spacing } \\
\text { (m) }\end{array}$} & \multirow{2}{*}{$\begin{array}{l}\text { Population } \\
\text { density } \\
\left(\text { plants } \mathrm{m}^{-2}\right)\end{array}$} & \multirow{2}{*}{$\begin{array}{l}\text { Maximum } \\
\text { LAI }\left(\mathbf{m}^{2} \mathbf{m}^{-2}\right)\end{array}$} & \multirow[t]{2}{*}{ Purpose } \\
\hline & & & & & Date & DOY & Date & DOY & Date & DOY & & & & \\
\hline \multirow[t]{6}{*}{ Lincoln } & \multirow[t]{3}{*}{2004} & \multirow[t]{3}{*}{ NE3001 } & \multirow[t]{3}{*}{$\mathrm{SD}$} & \multirow[t]{3}{*}{3.0} & \multirow[t]{3}{*}{ May 10} & \multirow[t]{3}{*}{131} & \multirow[t]{3}{*}{ June 22} & \multirow[t]{3}{*}{174} & \multirow[t]{3}{*}{ September 6} & \multirow[t]{3}{*}{250} & 0.762 & 27.7 & 5.8 & Model parameterization \\
\hline & & & & & & & & & & & 0.381 & 29.0 & 6.4 & Model evaluation \\
\hline & & & & & & & & & & & 0.381 & 45.9 & 7.6 & Model parameterization \\
\hline & \multirow[t]{3}{*}{2005} & NE3001 & SD & 3.0 & May 10 & 130 & June 20 & 171 & September 6 & 249 & 0.762 & 38.9 & 6.4 & Model evaluation \\
\hline & & \multirow{2}{*}{ P93M11 } & \multirow{2}{*}{ ID } & \multirow[t]{2}{*}{3.1} & \multirow[t]{2}{*}{ May 10} & \multirow[t]{2}{*}{130} & \multirow[t]{2}{*}{ June 19} & \multirow[t]{2}{*}{170} & \multirow[t]{2}{*}{ September 8} & \multirow[t]{2}{*}{251} & 0.762 & 37.2 & 7.0 & Model parameterization \\
\hline & & & & & & & & & & & 0.381 & 44.4 & 7.8 & Model parameterization \\
\hline \multirow[t]{2}{*}{ Mead } & 2004 & Р93В09 & ID & 3.0 & June 8 & 160 & July 18 & 200 & September 24 & 268 & 0.762 & 31.5 & 5.0 & Model parameterization \\
\hline & 2006 & P93M11 & ID & 3.1 & May 22 & 142 & June 23 & 174 & September 9 & 252 & 0.762 & 30.5 & 5.3 & Model evaluation \\
\hline
\end{tabular}

SD: semi-determinate; ID: indeterminate; DOY: day of year.

\section{Material and methods}

\subsection{Field experiments}

Data for model development were obtained from irrigated field experiments conducted in two research stations of the University of Nebraska, at Lincoln, NE (40.49"N, 96 39"W, 357 m a.s.l.) in 2004 and 2005 (Table 1) and at Mead, NE (41 $09^{\prime \prime} \mathrm{N}, 96^{\circ} 24^{\prime \prime} \mathrm{W}, 351 \mathrm{~m}$ a.s.l.) in 2004 and 2006. Agronomic management at Lincoln was optimized to achieve growth at a near yield potential level of soybean. Further experimental details for this site are provided elsewhere (Adviento-Borbe et al., 2007; Bastidas et al., 2008; Setiyono et al., 2007). Management practices in the large research field at Mead (Grant et al., 2007; Verma et al., 2005) followed best management practices for irrigated soybean production in Nebraska, including monitoring excellent weed and pest control and irrigation scheduling based on soil moisture and ET. Peak LAI obtained in these experiments ranged from 5.0 to 7.8 while soybean seed yield (at 13\% moisture) ranged from 3.7 to $5.3 \mathrm{Mg} \mathrm{ha}^{-1}$. Yields at Lincoln were generally high $\left(>5 \mathrm{Mg} \mathrm{ha}^{-1}\right.$ ), whereas yields at Mead were somewhat lower, probably due to less favorable soil conditions, including some soil physical restrictions for root growth.

In Lincoln, soybean cv. NE3001 (semi-determinate, MG 3.0) and Pioneer ${ }^{\bullet}$ P93M11 (indeterminate, MG 3.1) were grown on a conventionally tilled Kennebec silt loam (Cumulic Hapludolls). At Mead, soybean cv. Pioneer ${ }^{\circledR}$ P93B09 (indeterminate, MG 3.0) and Pioneer ${ }^{\circledR}$ P93M11 (indeterminate, MG 3.1) were grown on a no-till Tomek silt loam (Fine, smectitic, mesic Pachic Argiudolls). At both locations soybeans were grown in rotation with maize (Zea mays L.). The row spacing was 38.5 or $76 \mathrm{~cm}$ and the seeding density ranged from 37 to 49 viable seeds $\mathrm{m}^{-2}$ resulting in plant densities (at V2 stage) of 2546 plants $\mathrm{m}^{-2}$. Soybean was sown at approximately $2.5 \mathrm{~cm}$ depth in early, mid May, and early June with emergence dates shown in Table 1. Tillage in Lincoln consisted of fall plowing followed by field cultivation in spring for seedbed preparation. Weeds were controlled by pre-plant herbicide application and in-season manual hoeing (at Lincoln) or glyphosate application (at Mead). Pests and diseases were managed to avoid yield loss. Irrigation was applied through a solid-set sprinkler system (Lincoln) or a center pivot sprinkler system (Mead) and commenced at the R3 to R3.5 stage. Weekly water amounts were scheduled to replenish the estimated daily evapotranspiration calculated from data obtained by the automated weather stations located within $500 \mathrm{~m}$ of each experimental site. Such an irrigation regime is optimal for soybean in the Western Corn Belt (Specht et al., 1986). At Lincoln, nutrient applications were $80 \mathrm{~kg} \mathrm{~N} \mathrm{ha}^{-1}$ (at R3.5 stage), $45 \mathrm{~kg} \mathrm{P} \mathrm{ha}^{-1}$ and $85 \mathrm{~kg} \mathrm{Kha}^{-1}$ (pre-plant). At Mead, no fertilizer was applied to soybean, but soil nutrient levels were kept in optimal ranges through fertilizer applications during the maize phase of the crop rotation.

Phenology terminology and measurements were based on the system developed by Fehr and Caviness (1977). Leaf area was measured destructively using a LAI-3100 area meter (LI-COR, Lincoln, NE) 56 times at Lincoln and 7-12 times at Mead. The ground sampling area varied from 0.267 to $0.762 \mathrm{~m}^{2}$. Leaf area $\left(\mathrm{cm}^{2}\right.$ per plant) was converted to leaf area index $\left(\mathrm{m}^{2} \mathrm{~m}^{-2}\right)$ using population density measured in the harvest area at V2 and R7. Plants were manually harvested and machine threshed for grain yield determination in harvest areas of approximately $11-14 \mathrm{~m}^{2}$ size $(9.14 \mathrm{~m} \times 1.52 \mathrm{~m}$ for the $0.76 \mathrm{~m}$ row spacing or $9.14 \mathrm{~m} \times 1.15 \mathrm{~m}$ for the $0.385 \mathrm{~m}$ row spacing).

\subsection{Model development}

Soybean phenology was simulated as a function of temperature and photoperiod considering pre-induction and post-induction processes during the flowering phase (Setiyono et al., 2007). Leaf area index was simulated as a function of net leaf area per plant and population density (PD, Equation (1)). The term net leaf area is used to account for the simultaneous occurrence of leaf expansion and senescence at the whole plant and population level.

$$
\mathrm{LAI}=L_{\text {net }_{i}} \mathrm{PD}_{i} 10^{-4}
$$

where LAI is the leaf area index $\left(\mathrm{m}^{2} \mathrm{~m}^{-2}\right), L_{\text {net }_{i}}$ is the net leaf area $\left(\mathrm{cm}^{2}\right.$ plant $\left.^{-1}\right)$, PD is the population density (plants $\mathrm{m}^{-2}$ ) on the $i$ th day and $10^{-4}$ is a conversion factor from $\mathrm{cm}^{2}$ to $\mathrm{m}^{2}$.

Population density in Equation (1) was allowed to decrease linearly from the V2 stage to physiological maturity (R7) to account for post-emergence attrition (Equation (2)). Based on field observations in 2004 and 2006, the reduction in PD was modeled as a function of initial PD (measured at the V2 stage) and the estimated PD at the R7 stage, which was a function of the initial PD and the decrease in population density due to post-emergence attrition $\left(\mathrm{PD}_{\text {red }}\right)$, $\left(\mathrm{PD}_{\mathrm{V} 2}\left(\mathrm{PD}_{\text {red }} / 100\right)\right)$ in Equation (2).

$$
\begin{aligned}
& \mathrm{PD}_{i}=\mathrm{PD}_{\mathrm{V} 2}+\frac{\left(\mathrm{PD}_{\mathrm{V} 2}\left(\mathrm{PD}_{\mathrm{red}} / 100\right)-\mathrm{PD}_{\mathrm{V} 2}\right)\left(\mathrm{DOY}_{i}-\mathrm{DOY}_{\mathrm{V} 2}\right)}{\mathrm{DOY}_{\mathrm{R} 7}-\mathrm{DOY}_{\mathrm{V} 2}} \\
& \mathrm{PD}_{\mathrm{red}}=\frac{1-0.00412 \mathrm{PD}_{\mathrm{V} 2}}{0.067-0.0003 \mathrm{PD}_{\mathrm{V} 2}}
\end{aligned}
$$

where $\mathrm{PD}_{\mathrm{V} 2}$ is population density at the $\mathrm{V} 2$ stage (plants $\mathrm{m}^{-2}$ ), DOY is current day of year, $\mathrm{DOY}_{\mathrm{V} 2}$ is the day of year at the $\mathrm{V} 2$ stage, and $\mathrm{DOY}_{\mathrm{R} 7}$ is the day of year at the R7 stage.

Net leaf area was the difference between expanding and senescing leaf area (Equation (4)). Expanding and senescing leaf areas were determined based on the current daily rates of change and the previous 
values of these variables (Equations (5) and (6)).

$$
\begin{aligned}
& L_{\mathrm{net}_{i}}=L_{\mathrm{g}_{i}}-L_{\mathrm{s}_{i}} \\
& L_{\mathrm{g}_{i}}=L_{\mathrm{g}_{i-1}}+L_{\mathrm{g} x_{i}}\left(\mathrm{~d} x_{\mathrm{g}} / \mathrm{d} i\right) \\
& L_{\mathrm{s}_{i}}=L_{\mathrm{s}_{i-1}}+\Delta L_{\mathrm{s} x_{i}}\left(\mathrm{~d} x_{\mathrm{s}} / \mathrm{d} i\right)
\end{aligned}
$$

where $L_{\mathrm{g}_{i}}, L_{\mathrm{g}_{i-1}}, L_{s_{i}}$, and $L_{\mathrm{s}_{i-1}}$ are the current and previous days of expanding and senescing leaf area $\left(\mathrm{cm}^{2}\right.$ plant $\left.^{-1}\right)$, respectively, $\Delta L_{\mathrm{gx} i}$ is the current day change in expanding leaf area for a given change in cumulative $f(T)\left(\mathrm{cm}^{2}\right.$ plant ${ }^{-1}$ unit $\left.f(T)^{-1}\right), \Delta L_{\text {sx }}$ is the change in senescing leaf area for a given change in cumulative $f(T)\left(\mathrm{cm}^{2}\right.$ plant $^{-1}$ unit $\left.f(T)^{-1}\right), \mathrm{d} x_{\mathrm{g}} / \mathrm{d} i$ and $\mathrm{d} x_{\mathrm{s}} / \mathrm{d} i$ are changes in cumulative $f(T)$ during expansion and senescence per given change in calendar days, respectively, $f(T)$ is a temperature response function (Equation (11)). The inclusion of $\mathrm{d} x_{\mathrm{g}} / \mathrm{d} i$ and $\mathrm{d} x_{\mathrm{s}} / \mathrm{d} i$ terms in Equations (5) and (6) is necessary to transform the dimension of the rate of change in expansion and senescence from units of $f(T)$ to calendar days.

The rate of leaf expansion was simulated using the first derivative of a logistic function (Equations (8), (9), and (10)) and accounting for the effect of air temperature (Equation (11)) and the ratio of actual and potential transpiration (Equation (12)) on the rate of leaf expansion. The reason for using the derivative rather than the logistic function itself in simulating $L_{\mathrm{g}}$ was because the fluctuations of temperature and water availability directly alter the rate rather than the state variable of $L_{\mathrm{g}}$. The logistic function was used with the assumption that accumulative $L_{\mathrm{g}}$ is characterized by three distinct phases: $L_{\mathrm{g}}$ increases exponentially due to the rapid vegetative growth during the first phase; in the second phase, $L_{\mathrm{g}}$ increases at nearly a constant rate as leaf appearance and expansion proceed at a steady state; the final phase describes a diminishing rate of $L_{\mathrm{g}}$ as no more leaves are produced at the end of node appearance. The logistic function used for leaf expansion and senescence has the form of

$$
L=\frac{a}{1-b \exp (-c x)}
$$

where $a$ is the $L$-asymptote, $b$ is a shape factor, and $c$ is a rate constant (Milthorpe and Moorby, 1979) and the g and s subscripts represent expansion and senescence variables, respectively. The variable $b$ is related to $a$ and the intercept of $L$ at $x=0\left(L_{0}\right)$ (Equations (9) and (15)), while $c$ is related to $a$ and the maximum rate of change of $L$ (Equations (10) and (16)) (Milthorpe and Moorby, 1979).

$$
\begin{gathered}
\Delta L_{\mathrm{g} x_{i}}=\frac{\mathrm{d} L_{\mathrm{g}}}{\mathrm{d} x_{\mathrm{g}}}=\frac{a_{\mathrm{g}} b_{\mathrm{g}} c_{\mathrm{g}} \exp \left(-c_{\mathrm{g}} x_{\mathrm{g}}\right)}{\left[1+b_{\mathrm{g}} \exp \left(-c_{\mathrm{g}} x_{\mathrm{g}}\right)\right]^{2}} f\left(T_{\mathrm{g}}\right) f\left(\frac{\mathrm{TR}_{\mathrm{a}}}{\mathrm{TR}_{\mathrm{p}}}\right) \\
b_{\mathrm{g}}=\left(\frac{a_{\mathrm{g}}}{L_{\mathrm{g} 0}}\right)-1 \\
c_{\mathrm{g}}=\frac{4 \Delta L_{\mathrm{g} x \max }}{a_{\mathrm{g}}} \\
f(T)=\left\{\begin{array}{c}
\frac{2\left(T-T_{\min }\right)^{\alpha}\left(T_{\mathrm{opt}}-T_{\min }\right)^{\alpha}-\left(T-T_{\min }\right)^{2 \alpha}}{\left(T_{\mathrm{opt}}-T_{\min }\right)^{2 \alpha}} \\
\alpha=\frac{\ln (2)}{\ln \left[\left(T_{\max }-T_{\min }\right) /\left(T_{\mathrm{opt}}-T_{\min }\right)\right]}, T_{\min } \leq T \leq T_{\max } \\
0, \quad T<T_{\min } \text { or } T>T_{\max }
\end{array}\right.
\end{gathered}
$$

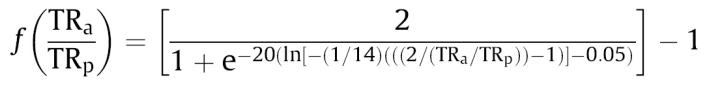

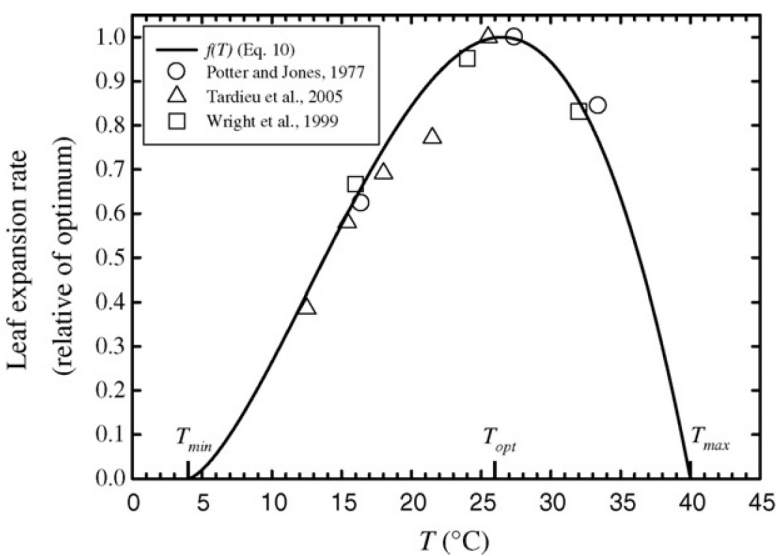

Figure 1. Soybean leaf expansion rate as a function of temperature; observed (symbols), simulated (line), based on published data. Minimum $\left(T_{\min }\right)$, optimum $\left(T_{\text {opt }}\right)$, and maximum $\left(T_{\max }\right)$ temperatures are 4,26 , and $40{ }^{\circ} \mathrm{C}$, respectively.

where $\Delta L_{\mathrm{gx} \max }$ is the maximum rate of change in expanding leaf area for a given change in $x_{\mathrm{g}}\left(\mathrm{cm}^{2}\right.$ plant ${ }^{-1}$ unit $\left.x_{\mathrm{g}}^{-1}\right), x_{\mathrm{g}}$ is the cumulative $f(T)$ since emergence, where $f(T)$ is a temperature response function related to phenology based on observed data (Equation (11)) with minimum $\left(T_{\min }\right)$, optimum $\left(T_{\mathrm{opt}}\right)$, and maximum $\left(T_{\max }\right)$ temperatures of 0,33 , and $50{ }^{\circ} \mathrm{C}$, respectively. The temperature response function (Equation (11)) for leaf expansion $\left(f\left(T_{\mathrm{g}}\right)\right.$, Figure 1) takes the same form as for phenology but with different $T_{\text {min }}, T_{\text {opt }}$, and $T_{\text {max }}$, 4, 26, and $40{ }^{\circ} \mathrm{C}$, respectively (Potter and Jones, 1977; Tardieu et al., 2005; Wright et al., 1999). The water deficit response function for leaf expansion $\left(f\left(\mathrm{TR}_{\mathrm{a}} / \mathrm{TR}_{\mathrm{p}}\right)\right.$ is given by Equation (12). In the first iteration, a value of $2 \mathrm{~cm}^{2}$ plant ${ }^{-1}$ was used for $L_{\mathrm{g} 0}$ based on field measurements (expanded leaf area at emergence). For all other iterations the value of $L_{\mathrm{g} 0}$ in the simulation was determined from the logistic equation (Equation (7)) at $x_{\mathrm{g}}=0$.

A beta function (Wang and Engel, 1998) and data from the literature were used to describe the temperature response of soybean leaf expansion $f\left(T_{\mathrm{g}}\right)$ (Figure 1). The minimum $\left(T_{\mathrm{min}}\right)$, optimum $\left(T_{\mathrm{opt}}\right)$, and maximum $\left(T_{\max }\right)$ temperatures for $f\left(T_{\mathrm{g}}\right)$ were 4,26 , and $40{ }^{\circ} \mathrm{C}$, respectively. The effect of water availability on leaf expansion was taken into account by using a modified simple water balance model (Campbell and Diaz, 1988) to calculate the ratio of actual and potential transpiration. The soil-water balance model used a tipping bucket (cascade) type approach. Precipitation and irrigation were inputs added to the top soil layer while accounting for runoff (based on Stewart et al., 1976) and interception by leaf surfaces (assuming that a maximum of $1 \mathrm{~mm}$ of precipitation can be intercepted as function of LAI). For each soil layer in excess of field capacity, water moved downward to the next soil layer. Water leaving the lowest layer was lost as drainage. Evapotranspiration was separated into evaporation and transpiration. Evaporation was assumed to occur only from the first soil layer, which in this simulation was $0.1 \mathrm{~m}$ thick. The remaining 19 layers were $0.145 \mathrm{~m}$ thick. Transpiration was determined from each layer, not including the first soil layer, and controlled by the root depth, LAI and soil-moisture content. Potential transpiration was determined based on reference ET (which was determined from data collected at a nearby automated weather station) and the previous day's simulated LAI. The new soil-moisture content was calculated as the water-balance residual. Rooting depth (RD) (m) was simulated based on a logistic function of stage of development:

$$
\mathrm{RD}=\left[\mathrm{RD}_{0}-\frac{\mathrm{RD}_{\max }}{1+b_{\mathrm{r}}}\right]+\frac{\mathrm{RD}_{\max }}{1+b_{\mathrm{r}} \exp \left(-c_{\mathrm{r}} x_{\mathrm{r}}\right)}, \quad x_{r}=\frac{i-\mathrm{VE}}{\mathrm{R} 7-\mathrm{VE}}
$$


where $\mathrm{RD}_{\text {max }}$ is the maximum root depth $(1.6 \mathrm{~m}), \mathrm{RD}_{0}$ is the root depth at emergence $(0.036 \mathrm{~m}), b_{\mathrm{r}}$ (shape factor) and $c_{\mathrm{r}}$ (rate constant) are logistic coefficients for root depth (94.24 and 9.35 , respectively), VE is the day of emergence, R7 is the day of year when physiological maturity occurred, $i$ was the current day of year. The value of $\mathrm{RD}_{\max }, \mathrm{RD}_{0}, b_{\mathrm{r}}$, and $c_{\mathrm{r}}$ were determined based on data from Mayaki et al. (1976). Dardanelli et al. (1997) calculated root depths for soybean maturity groups III, V, and VII of $1.3,1.9$, and $2.3 \mathrm{~m}$, respectively. Thus, the use of $1.6 \mathrm{~m}$ for $\mathrm{RD}_{\max }$ in this simulation is reasonable. The water balance model was modified to allow reference potential evapotranspiration (ETp) as input to the model rather than being calculated. Such modification was necessary considering the calculation of ETp in the original model was derived under a semiarid climate and may not apply under the climate of this study. To reduce further uncertainty in the water balance model, solar radiation and LAI were made input parameters, rather than calculated as in the original model. Functions describing leaf expansion response to the ratio of actual and potential transpiration were derived from Sinclair (1986) and Sinclair and Ludlow (1986).

It was assumed that the senescing leaf area followed a pattern similar to that of the expanding leaf area. Even though water stress is known to accelerate senescence during the seed filling period (Egli and Bruening, 2004), it was not considered in the simulation of senescence in this approach for two reasons: (1) irrigation after the beginning of pod stage (R3) was expected to avoid water deficits throughout the seed filling period, and (2) water stress, if occurring early in plant development, may not accelerate senescence as the plants respond to water stress by producing smaller and less leaves (Frederick et al., 1991). Muchow (1985) showed that water stress prior to full soybean canopy coverage did not increase leaf loss but greatly reduced early leaf area. In this simulation study, senescence was initialized at the R1 stage based on the assumption that monocarpic senescence in soybean begins at flowering (Burke et al., 1984). The rate of change in senesced leaf area was simulated using the first derivative of the logistic function described in Equation (7), but with a different temperature response function:

$$
\begin{aligned}
& \Delta L_{\mathrm{s} X}=\frac{\mathrm{d} L_{\mathrm{s}}}{\mathrm{d} x_{\mathrm{s}}}=\frac{a_{\mathrm{s}} b_{\mathrm{s}} c_{\mathrm{s}} \exp \left(-c_{\mathrm{s}} x_{\mathrm{s}}\right)}{\left[1+b_{\mathrm{s}} \exp \left(-c_{\mathrm{s}} x_{\mathrm{s}}\right)\right]^{2}} f\left(T_{\mathrm{S}}\right) \\
& b_{\mathrm{s}}=\left(\frac{a_{\mathrm{s}}}{L_{\mathrm{s} \tilde{\sigma}}}\right)-1 \\
& c_{\mathrm{S}}=\frac{4 \Delta L_{\mathrm{s} x \max }}{a_{\mathrm{s}}} \\
& f\left(T_{\mathrm{S}}\right)= \begin{cases}\frac{T-4}{(30-4)}, & T>4 \\
0, & T \leq 4\end{cases}
\end{aligned}
$$

where $\Delta L_{s x \text { max }}$ is the maximum rate of change in senescing leaf area for a given change in $x_{s}\left(\mathrm{~cm}^{2}\right.$ plant $^{-1}$ unit $\left.x_{s}^{-1}\right), x_{s}$ is the cumulative $f(T)$ since $\mathrm{R} 1$ with minimum $\left(T_{\min }\right)$, optimum $\left(T_{\text {opt }}\right)$, and maximum $\left(T_{\max }\right)$ temperatures of 0,33 , and $50{ }^{\circ} \mathrm{C}$, respectively, $f\left(T_{s}\right)$ is temperature response function describing acceleration of senescence due to increasing temperature $(T)$. In the first iteration, a value of $6 \mathrm{~cm}^{2}$ plant $^{-1}$ was assumed for $L_{\mathrm{s} 0}$ (initial leaf area senescence). Similar to the expansion phase, for all other iterations the value of $L_{\mathrm{s} 0}$ in the simulation was determined from the logistic equation at $x_{s}=0$ (Equation (7)).

The use of cumulative $x_{s}$ in Equation (14) allowed the effect of temperature on phenology to drive senescence, emphasizing the concept that senescence is a highly regulated process (Gepstein, 2004; Guo et al., 2004). The acceleration of the senescence rate due to high temperature was accounted for by $f\left(T_{\mathrm{s}}\right)$, which was similar to the approach used in the WOFOST-model (Supit and Van der Groot, 2003) in determining the physiological age of the leaf.

\subsection{Statistical analysis}

Five field data sets (Table 1) and literature data from Buttery (1969) on the effect of population density on maximum leaf area and the influence of air temperature on the rate of leaf expansion were used for model parameterization $\left(a_{\mathrm{g}}, L_{\mathrm{g} 0}, \Delta L_{\mathrm{g} x \max }, a_{\mathrm{s}}, L_{\mathrm{s} 0}, \Delta L_{\mathrm{s} x \max }\right)$. Non-linear regression analyses were conducted among model parameters and population density levels using the NLIN procedure (SAS Institute, 1999). Functions used in the non-linear regression analyses were selected using the Curve Expert (Hyams, 2001). The NLIN procedure was used to obtain the $P$-value associated with non-linear regression analyses. Model evaluation against independent field observations was done for three field data sets (Table 1). Simulated LAI were compared with the observed values using the root mean square error (RMSE) calculated as:

$$
\text { RMSE }=\sqrt{\frac{\sum\left(s_{i}-o_{i}\right)^{2}}{n}}
$$

where $s_{i}=$ simulated data on the $i$ th day, $o_{i}=$ observed data on the $i$ th day, $n=$ number of pairs of simulated and observed data.

\section{Results}

\subsection{Model parameterization}

Model parameterization was achieved by determining the maximum expanding and senescing leaf area $\left(a_{\mathrm{g}}\right.$ and $\left.a_{\mathrm{s}}\right)$, the intercept of $L$ at $x=0\left(L_{\mathrm{g} 0}\right.$ and $\left.L_{\mathrm{s} 0}\right)$, and the maximum rate of expansion and senescence $\left(\Delta L_{\mathrm{g} x \max }\right.$ and $\left.\Delta L_{s x \max }\right)$ as independent variables, while treating shape factors for expansion and senescence $\left(b_{\mathrm{g}}\right.$ and $\left.b_{s}\right)$ and rate constants for expansion and senescence $\left(c_{\mathrm{g}}\right.$ and $\left.c_{\mathrm{s}}\right)$ as dependent variables. Field observations in 2004 and 2005 in Lincoln suggested that $L_{\mathrm{g} 0}$ was associated with the average air temperature during the first 6 days after emergence $\left(\mathrm{TL}_{\mathrm{g} 0}\right)$, while the initial leaf senescence $\left(L_{\mathrm{s} 0}\right)$ was set at a constant value of $8 \mathrm{~cm}^{2}$ plant $^{-1}$. A maximum $L_{\mathrm{g} 0}\left(L_{\mathrm{g} 0 \mathrm{max}}\right)$ of $52 \mathrm{~cm}^{2}$ plant $^{-1}$ and the temperature function given by Equation (11) were used to calculate $L_{\mathrm{g} 0}$. The value of $L_{\mathrm{g} 0 \max }$ was obtained from field observations of cv. NE3001 in 2004 and 2005 in Lincoln. The temperature function for $L_{\mathrm{g} 0}$ had minimum, optimum, and maximum average temperatures of 7,22 , and $32^{\circ} \mathrm{C}$, respectively. The relatively

\begin{tabular}{|c|c|c|c|c|}
\hline Variables & $a_{\mathrm{g}}$ & $a_{\mathrm{s}}$ & $\Delta L_{g x \max }$ & $\Delta L_{s x \max }$ \\
\hline $\mathrm{PD}$ & $0.0012^{\mathrm{a}}$ & $0.0375^{b}$ & $0.0017^{b}$ & $0.3928^{b}$ \\
\hline$a_{\mathrm{g}}$ & - & $0.0003^{b}$ & $0.5468^{b}$ & $0.0007^{b}$ \\
\hline$a_{\mathrm{s}}^{\mathrm{s}}$ & - & - & $0.0813^{b}$ & $0.3704^{b}$ \\
\hline$\Delta L_{\mathrm{gIP}}$ & - & - & - & $0.4227^{b}$ \\
\hline \multicolumn{5}{|c|}{$\begin{array}{l}\text { a Hoerl function }\left(y=a b^{x} x^{c}\right) . \\
{ }^{\mathrm{b}} \text { Quadratic function } \quad\left(y=a+b x+c x^{2}\right) ; \quad a_{\mathrm{g}}=\text { maximum expanding leaf area } \\
\left.\mathrm{m}^{2} \text { plant } \mathrm{t}^{-1}\right) ; a_{\mathrm{s}}=\text { maximum senescing leaf area }\left(\mathrm{cm}^{2} \text { plant }{ }^{-1}\right) ; \Delta L_{\mathrm{gx} \text { max }}=\text { maximum rate of } \\
\text { ange in expanding leaf area }\left(\mathrm{cm}^{2} \text { plant }{ }^{-1} \text { unit } x_{\mathrm{g}}^{-1}\right) \text {, where } x_{\mathrm{g}} \text { is cumulative } f(T) \text { since emer- } \\
\text { nce and } f(T) \text { is temperature function (Equation }(10)) ; \Delta L_{\text {sx max }}=\text { maximum rate of change } \\
\text { senescing leaf area }\left(\mathrm{cm}^{2} \text { plant }{ }^{-1} \text { unit } x_{\mathrm{s}}^{-1}\right) \text {, where } x_{\mathrm{s}} \text { is cumulative } f(T) \text { since } \mathrm{R} 1 \text { and } f(T) \\
\text { temperature function (Equation }(10)) ; \mathrm{PD}=\text { population density }\left(\times 10^{-1} \text { plant } \mathrm{m}^{-2}\right) \text {. }\end{array}$} \\
\hline
\end{tabular}
low optimum and maximum temperatures were in agreement with the observation by Hesketh et al. (1973) showing that leaf growth in

Table 2. The levels of significance for non-linear regression tests ( $P$-values) of variables associated with rate of change of expanding and senescing leaf area 
Table 3. Equations determining the variables controlling the rate of change in expanding and senescing leaf area

\begin{tabular}{|c|c|c|c|c|}
\hline Stem termination type & $a_{\mathrm{g}}$ & $a_{\mathrm{s}}$ & $\Delta L_{g x \max }$ & $\Delta L_{s x \max }$ \\
\hline $\begin{array}{l}\text { Semi-determinate } \\
\text { Indeterminate }\end{array}$ & $\begin{array}{l}69716\left(1.00055^{\mathrm{PD}}\right) \mathrm{PD}^{-0.5721} \\
69693\left(1.00089^{\mathrm{PD}}\right) \mathrm{PD}^{-0.5793}\end{array}$ & $29008-19.711 a_{\mathrm{g}}+0.003483 a_{\mathrm{g}}^{2}$ & $303.52-1.0759 \mathrm{PD}+0.00137 \mathrm{PD}^{2}$ & $3161.9-2.1436 a_{g}+0.0003672 a_{g}^{2}$ \\
\hline
\end{tabular}

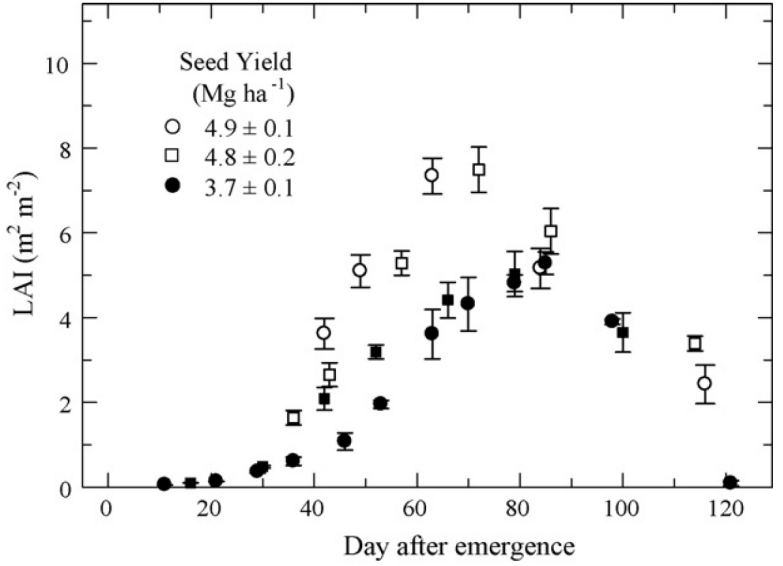

Figure 2. Observed LAI in Lincoln ( $\mathrm{c}, \mathrm{cv} . \mathrm{NE} 3001$ in 2004 at 49.5 plant $\mathrm{m}^{-2}$; 口, cv. P93M11 in 2005 at 37.2 plant $\left.\mathrm{m}^{-2}\right)$ and at Mead (•, cv. P93B09 in 2004 at 31.5 plant $\mathrm{m}^{-2} ; \mathbf{m}$, cv. P93M11 in 2006 at 30.5 plant $\mathrm{m}^{-2}$. Bars indicate standard error from four replications.

young soybean plants at an average daily temperature above $20{ }^{\circ} \mathrm{C}$ was greatly altered, inducing malformed shape and reduced area.

Non-linear regression analyses of the remaining four variables, $a_{\mathrm{g}}$, $a_{\mathrm{s}}, \Delta L_{\mathrm{gx} \max }$, and $\Delta L_{\mathrm{s} x \max }$, suggested that $a_{\mathrm{g}}$ and $\Delta L_{\mathrm{g} x \max }$ were correlated with population density, while $a_{s}$ and $\Delta L_{\mathrm{s} x \max }$ were correlated with $a_{\mathrm{g}}$ at $P<0.01$ (Table 2). Hence $a_{\mathrm{g}}$ and $\Delta L_{\mathrm{g} x \max }$ can be calculated as a function of population density (PD) $\left(a_{g}\right.$ with a Hoerl function, $y=a b^{x} x^{c} ; \Delta L_{\mathrm{g} x \max }$ with a quadratic function, $\left.y=a+b x+c x^{2}\right)$, while $a_{\mathrm{s}}$ and $\Delta L_{\mathrm{s} x \text { max }}$ are quadratic functions $\left(y=a+b x+c x^{2}\right)$ of $a_{\mathrm{g}}$. Parameter estimates for these functions are given in Table 3. LAI simulation with the dependent datasets had an RMSE of $0.25 \mathrm{~m}^{2} \mathrm{~m}^{-2}$.

\subsection{Model evaluation}

Under optimal growth conditions encountered in field situations, the model input parameters can be reduced to only two indepen-
Table 4. Model parameter adjustment for the case of relatively slow initial leaf growth (Mead 2004 data)

\begin{tabular}{cc}
\hline Parameter & Value adjustment \\
\hline $\mathrm{TL}_{\mathrm{g} 0}$ & $0.60 \times$ \\
$c_{\mathrm{g}}$ & $0.80 \times$ \\
$a_{\mathrm{s}}$ & $1.12 \times$ \\
$b_{\mathrm{s}}$ & $1.80 \times$ \\
$c_{\mathrm{s}}$ & $0.75 \times$ \\
$c_{\mathrm{r}}$ & $0.95 \times$ \\
\hline
\end{tabular}

$\mathrm{TL}_{\mathrm{g} 0}=$ average air temperature during the first 6 days after emergence $\left({ }^{\circ} \mathrm{C}\right) ; c_{\mathrm{g}}=$ rate constant of logistic leaf expansion; $a_{\mathrm{s}}=$ maximum senescing leaf area; $b_{\mathrm{s}}=$ shape factor of logistic leaf senescence; $c$ = rate constant of logistic leaf senescence; $c$ = rate constant of logistic root depth expansion. The " $x$ " represents the value of the factor to multiply the original parameter to modify it for the Mead conditions.

dent variables, population density and stem termination type (Table 3). Comparison between the two sites indicated a slower initial leaf growth at Mead as compared to Lincoln (Figure 2). Reasons for this difference were not fully clear, but they may include factors such as differences in temperature regimes due to different tillage (cooler soil/ soil surface temperature during emergence under no-till cultivation at Mead vs. tilled soil at Lincoln), differences in soil fertility levels at planting (including somewhat higher residual soil nitrate levels at Lincoln than at Mead), differences in nodulation, or soil physical constraints affecting root growth at the Mead site. Hence, based on the results of the sensitivity analyses, the Mead data set in 2004 was used to adjust six model parameters (Table 4 ) to account for these site-specific differences.

The model was capable of simulating the pattern of LAI in soybean under optimum conditions at Lincoln and, with modification of the six parameters, at Mead. Simulated LAI patterns included an exponential increase at the beginning of leaf growth followed by a bellshaped pattern around the peak and a decline toward physiological maturity (Figure 3). Leaf expansion reached a plateau near the attainment of the maximum number of nodes. The model was also able to capture the variability in LAI across years, cultivars, and population densities, and locations (Figure 3). (a)

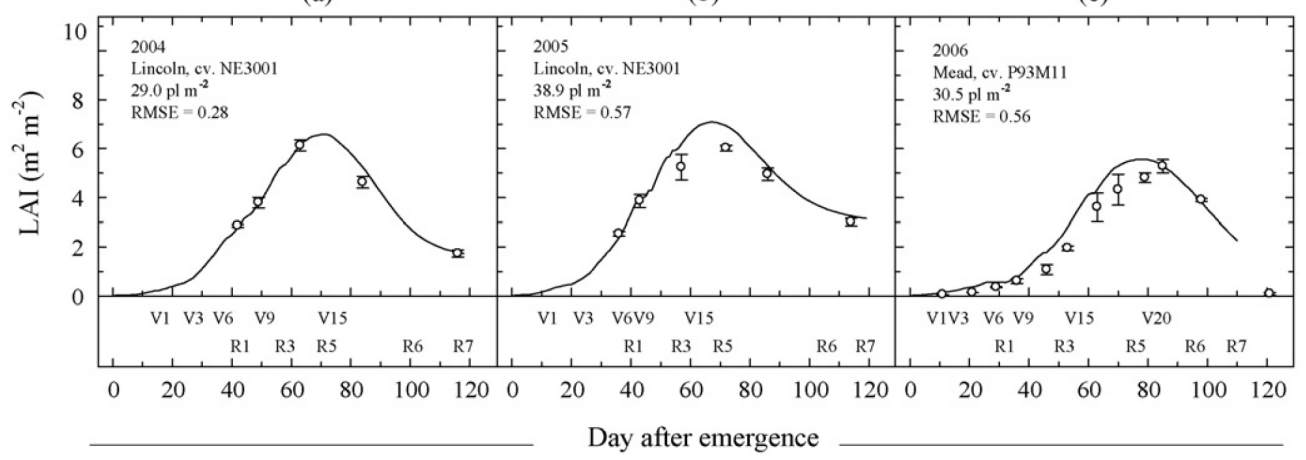

Figure 3. Simulated (lines) and observed (symbols) LAI for cv. NE3001 in 2004 at 29.0 plant $\mathrm{m}^{-2}$ (a) and in 2005 at 38.9 plant $\mathrm{m}^{-2}$ (b) in Lincoln, NE, and cv. P93M11 at 30.5 plant $\mathrm{m}^{-2}$ at Mead, NE in 2006 (c). These data sets were not included in model parameterization. RMSE: root mean square error. R and V stages of soybean development are shown in panel 2. 
(a)

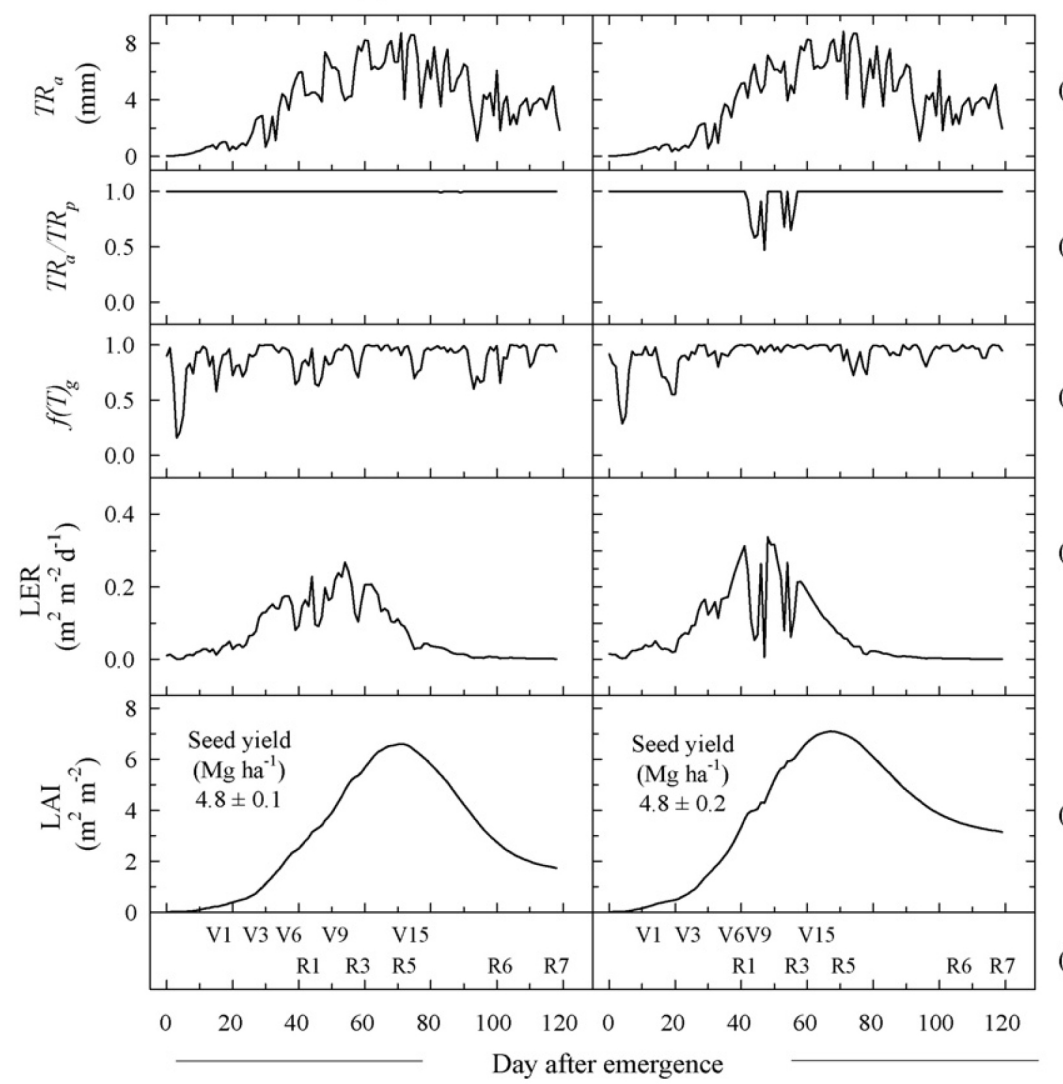

Figure 4. Simulation of actual transpiration $\left(\mathrm{TR}_{\mathrm{a}}\right)$ (panel 1) and its ratio over the potential transpiration $\left(\mathrm{TR}_{\mathrm{a}} / \mathrm{TR}_{\mathrm{p}}\right)$ (panels 2$)$, value of temperature function for leaf expansion $\left(f\left(T_{\mathrm{g}}\right)\right.$ ) (panel 3), leaf expansion rate (LER) (panel 4), and LAI (panels 5) for cv. NE3001 in 2004 at 29.0 plant $\mathrm{m}^{-2}$ (a) and in 2005 at 38.9 plant $\mathrm{m}^{-2}$ (b) in Lincoln, NE. R and V stages of soybean development are shown in panel 6.

(a)

Cv. NE3001, 2004

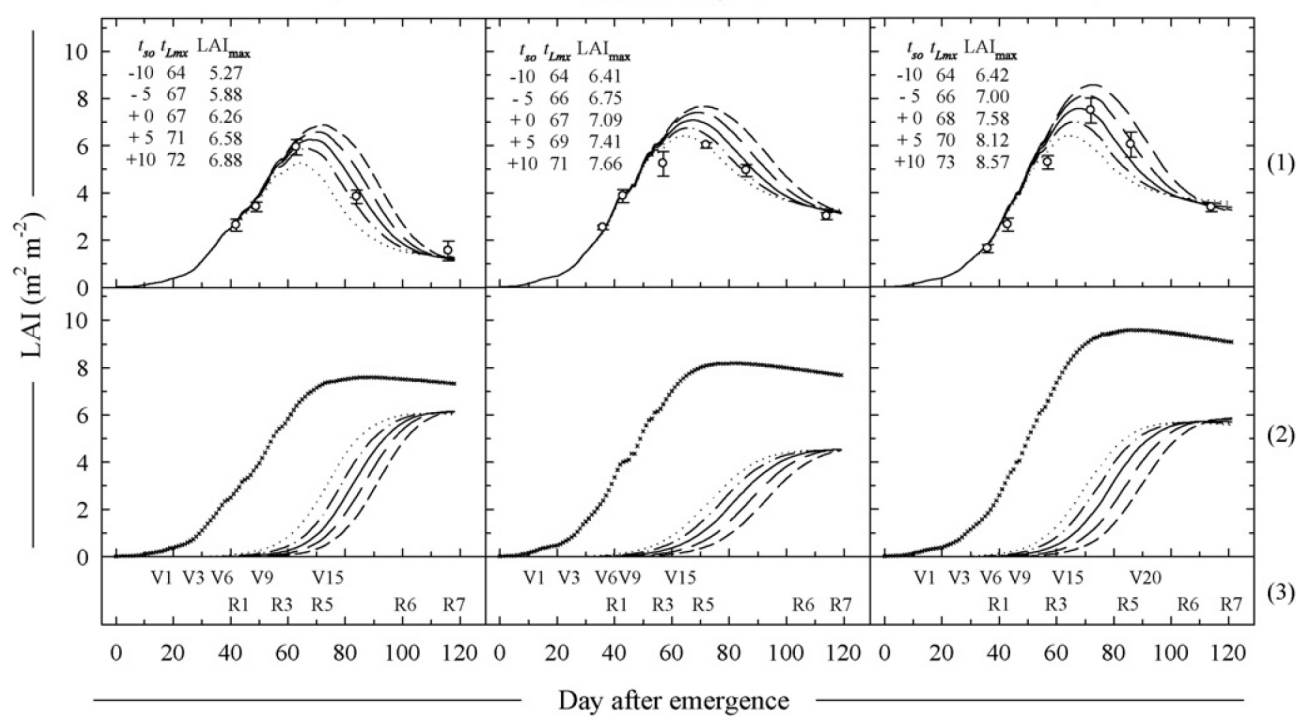

Figure 5. Simulated LAI as affected by the time of initiation of senescence $\left(t_{\mathrm{so}}\right)$ for $\mathrm{cv}$. NE3001 in 2004 at $27.7 \mathrm{plant} \mathrm{m}^{-2}$ (a) and cv. P93M11 in 2005 at 37.2 plant $\mathrm{m}^{-2}$ (b). Simulated net (lines) and observed ( $\mathrm{O}$ ) LAI are shown in panel 1 with bars indicating standard errors from four replications, while simulated expanding cumulated $(x)$ and senescing (lines) LAI are shown in panel 2. The initiation of senescence treatments were control (at R1) (-), control $+5 \mathrm{~d}(--)$, control $+10 \mathrm{~d}(--)$, control $-5 \mathrm{~d}(-\cdot-\cdot)$, and control $-10 \mathrm{~d}(\cdots)$. The simulated time of maximum LAI $\left(t_{\mathrm{Lmx}}\right)\left(\right.$ day after emergence) and the value of maximum LAI $\left(\mathrm{LAI}_{\max }\right)\left(\mathrm{m}^{2} \mathrm{~m}^{-2}\right)$ associated with treatments of initiation of senescence are shown as inserts in panel 1. $\mathrm{R}$ and $\mathrm{V}$ stages of soybean development are shown in panel 3. 
(a)

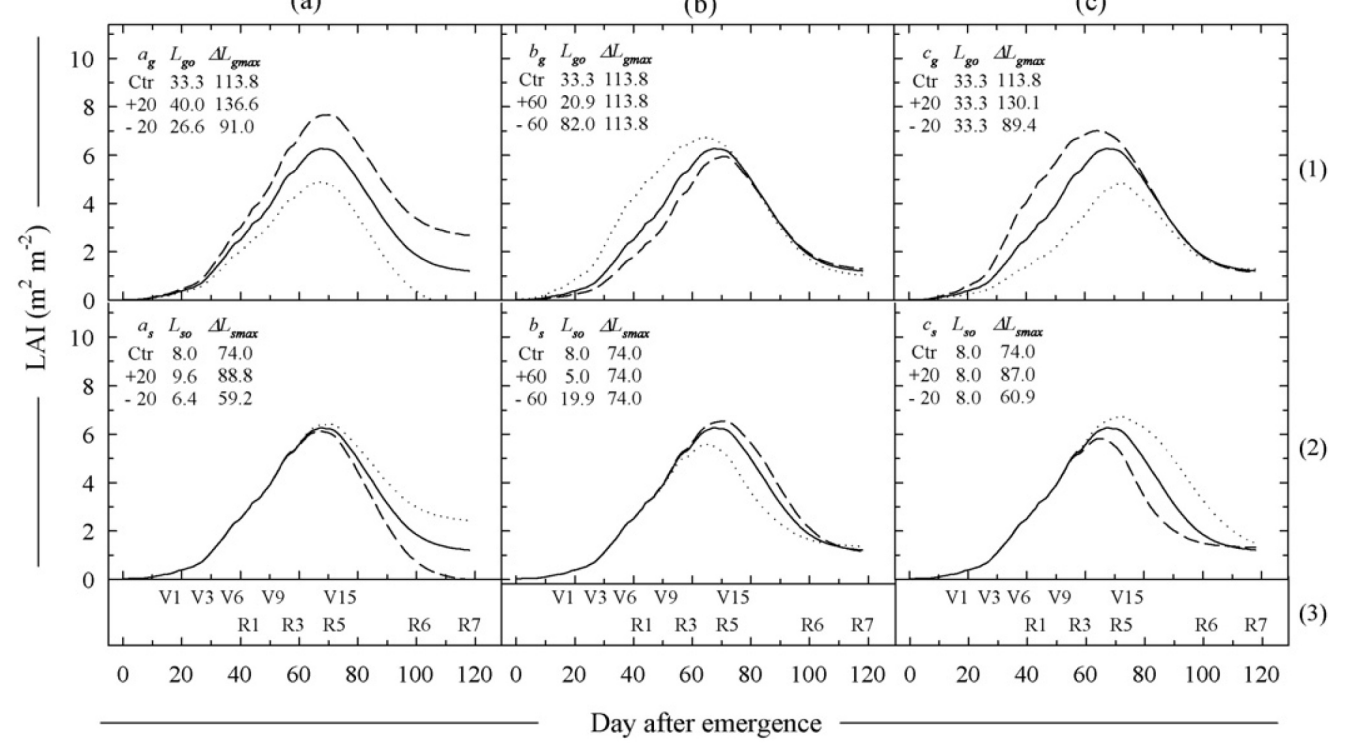

Figure 6. Simulated LAI as affected by modification of logistic equation coefficients describing leaf expansion $\left(a_{\mathrm{g}}, b_{\mathrm{g}}, c_{\mathrm{g}} ;\right.$ panel 1$)$ and senescence $\left(a_{s}, b_{\mathrm{s}}, c_{\mathrm{s}}\right.$; panel 2$)$. Each of the logistic coefficients, $a_{\mathrm{g}}(1 \mathrm{a}), a_{\mathrm{s}}(2 \mathrm{a}), b_{\mathrm{g}}(1 \mathrm{~b}), b_{\mathrm{s}}(2 \mathrm{~b}), c_{\mathrm{g}}(1 \mathrm{c})$, and $c_{\mathrm{s}}(2 \mathrm{c})$, was modified by increasing (- -) or decreasing $(\ldots$.$) the value by 20 \%\left(a_{\mathrm{g}}, a_{\mathrm{s}}, c_{\mathrm{g}}\right.$, and $\left.c_{\mathrm{s}}\right)$ or $60 \%\left(b_{\mathrm{g}}\right.$ and $\left.b_{\mathrm{s}}\right)$ as compared to the control, $\mathrm{Ctr}(-)$. The control coefficients are those of cv. NE3001 in 2004 at 27.7 plant $\mathrm{m}^{-2}$. The two associated variables, intercept of $L$ at $x=0\left(L_{\mathrm{g} 0}\right.$ and $\left.L_{\mathrm{s} 0}\right)$ and maximum rate of change of leaf area $\left(\Delta L_{\mathrm{g} \max }\right.$ and $\left.\Delta L_{\mathrm{s} \max }\right)$ are shown as insert in panels 1 and 2 . R and $\mathrm{V}$ stages of soybean development are shown in panel 3 . To illustrate the sensitivity of the $b$ coefficients, $b_{\mathrm{g}}$ and $b_{\mathrm{s}}$ were modified by 60 rather than $20 \%$ as the case of the other coefficients.

Using the generalized parameters (Table 3 and Table 4), the overall RMSE value of the simulations with the independent data sets at the two locations was $0.52 \mathrm{~m}^{2} \mathrm{~m}^{-2}$. For comparison, with independent data sets in central Missouri, CROPGRO model simulated soybean LAI with an overall RMSE of $1.07 \mathrm{~m}^{2} \mathrm{~m}^{-2}$ (Wang et al., 2003). The accuracy in LAI simulation with the model described here was reasonable considering that the observed LAI values ranged from 0 to 7.8 with average and maximum standard errors of 0.31 and $1.10 \mathrm{~m}^{2} \mathrm{~m}^{-2}$, respectively. In some cases, slight overestimation of simulated LAI was evident (Figure 3b and c), typically near the peak LAI. Such overestimation of LAI indicates that under particular situations, LAI expansion becomes source limiting.

Figure 4 compares LAI simulation in Lincoln in 2004 vs. 2005 showing different environmental factors influencing leaf expansion (temperature and water availability). The ratio of actual and potential transpiration $\left(\mathrm{TR}_{\mathrm{a}} / \mathrm{TR}_{\mathrm{p}}\right.$ ) remained optimum throughout the growing season in 2004 while in 2005 there was a decline in $\mathrm{TR}_{\mathrm{a}} / \mathrm{TR}_{\mathrm{p}}$ near the time of maximum leaf expansion rate. This apparent water stress during early growth stage in 2005 , however, was not severe enough to reduce yield. The simulated temperature function for leaf expansion indicates a relatively more optimum in 2005 than in 2004.

\subsection{Sensitivity analysis}

Sensitivity of simulated LAI to the time of initial senescence is shown in Figure 5 (panel 1). Delaying the time of senescence by 510 days caused a delay in time of maximum LAI by $2-4$ days, and an increase in LAI by $0.32-0.54 \mathrm{~m}^{2} \mathrm{~m}^{-2}$ (averaging over both cultivars). Simulated expanding and senescing leaf area are shown in panel 2. A slight decline in expanding LAI after approaching the $L_{\mathrm{g}}$ asymptote was associated with the simulated decreased population density. The shape of the senescing LAI curve along the $x$-axis was associated with the imposed modification in time of initiation of senescence.

The effect of varying the values of the logistic function coefficients associated with leaf expansion $\left(a_{\mathrm{g}}, b_{\mathrm{g}}, c_{\mathrm{g}}\right)$ and senescence $\left(a_{\mathrm{s}}, b_{\mathrm{s}}, c_{\mathrm{s}}\right)$ on simulated leaf area is shown in Figure 6. Both $a_{\mathrm{g}}$ and $c_{\mathrm{g}}$ had a positive effect on the simulated maximum LAI in that an increase in these variables caused an increase in maximum LAI. Such increases in maximum LAI by $a_{\mathrm{g}}$ and $c_{\mathrm{g}}$ were associated with increases in the maximum

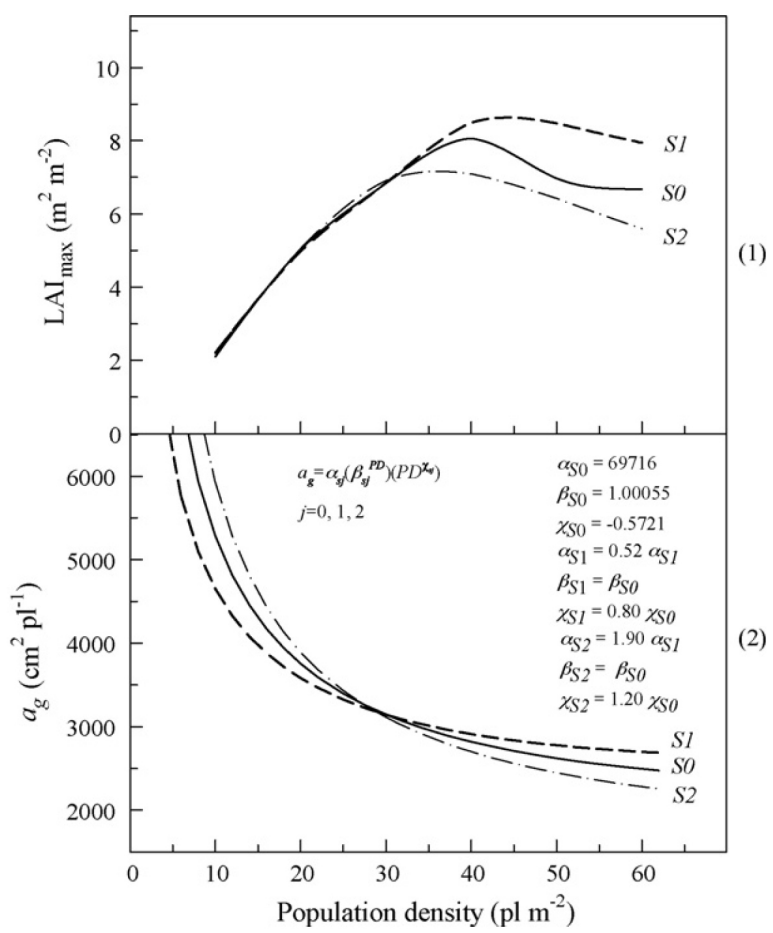

Figure 7. Simulated responses of maximum LAI $\left(\mathrm{LAI}_{\max }\right)$ to population density (PD) for different sets of parameters describing $a_{\mathrm{g}}$ (panel 1). These different sets of parameters and the Hoerl function describing the relationship between $a_{\mathrm{g}}$ and the parameters $\alpha_{s j}$, $\beta_{s j}$, and $\chi_{s j}$ are given on panel 2. The control set $(S O)$ were based on those of cv. NE3001. The $S 1$ parameter set represents a lesser values of $\alpha_{s j}$ and $\chi_{s j}$ while the $S 2$ parameters set represents greater value of $\alpha_{s j}$ and $\chi_{s j}$ as indicated by the multiplier of $\alpha_{S O}$ and $\chi_{S O}$. 


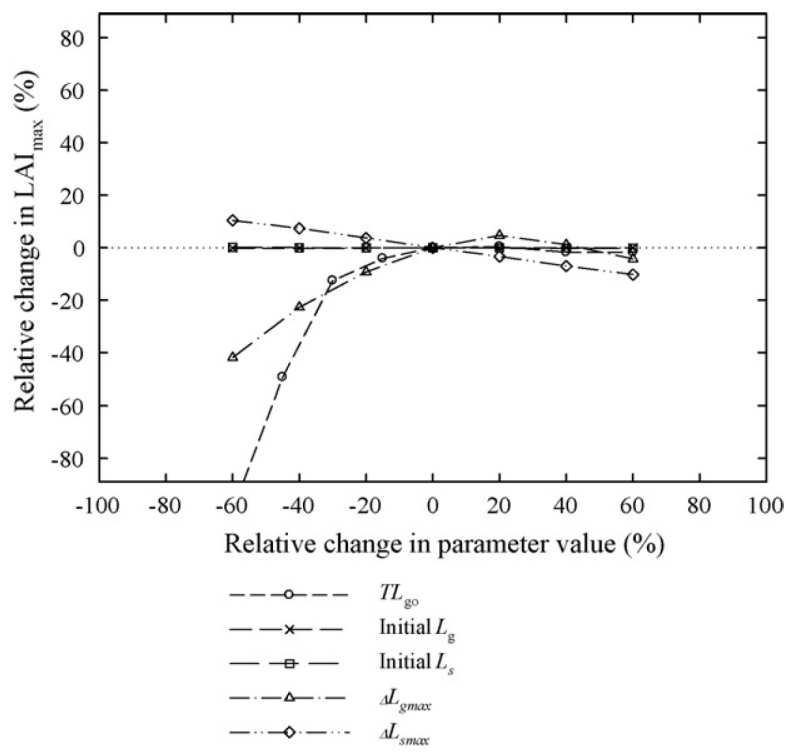

Figure 8. Simulated maximum LAI $\left(\mathrm{LAI}_{\max }\right)$ as affected by changes in key parameters associated with leaf expansion and senescence. The control parameters are those of $\mathrm{cv}$. NE3001. The control LAI ${ }_{\max }$ was based on simulation of $\mathrm{cv}$. NE3001 in 2004 at 27.7 plant $\mathrm{m}^{-2}$.

slope of expansion $\left(\Delta L_{\mathrm{g} x \max }\right)$. An increase in $a_{\mathrm{g}}$ also caused an increase in the initial rate of expansion as indicated by an increase in $L_{\mathrm{g} 0}$. An increase in $b_{\mathrm{g}}$ caused a reduction in maximum LAI due to a decreasing initial rate of leaf expansion. The corresponding logistic coefficients for senescence had the opposite trend in that $a_{\mathrm{s}}$ and $c_{\mathrm{s}}$ negatively affected maximum LAI (although the influence of $a_{\mathrm{s}}$ was smaller than $c_{s}$ ) while $b_{s}$ positively affected maximum LAI. The coefficients $b_{\mathrm{s}}$ and $c_{\mathrm{s}}$ were also unique in that they also control the time of maximum LAI.

The sensitivity of simulated maximum LAI ( $\mathrm{LAI}_{\max }$ ) to population density is shown in Figure 7. Simulated LAI max $_{\text {increased with }}$ increasing population density up to an optimum population density, thereafter $\mathrm{LAI}_{\max }$ declined due to the simulated decline of maximum plant leaf area with increasing population density. Figure 7 also shows the effect of modifying coefficients relating population density and individual plant leaf area (Table 3 ). As the population density increases, maximum plant leaf area $\left(a_{\mathrm{g}}\right)$ decreases. The parameter set $S 1$, defined in Figure 4 is less sensitive to changes in population density than the parameter set S2. Maximum LAI was reached at higher population density for the parameter set $S 1$ then for parameter set $S 2$ (Figure 6, panel 1).

Sensitivity analyses of simulated $\mathrm{LAI}_{\max }$ on the initial values of $L_{\mathrm{g}}$ and $L_{\mathrm{s}}$, air temperature during the first 6 days after emergence $\left(\mathrm{TL}_{\mathrm{g} 0}\right)$, and maximum rate of change of $L_{\mathrm{g}}\left(\Delta L_{\mathrm{g} x \max }\right)$ and $L_{\mathrm{s}}$ $\left(\Delta L_{s x \max }\right)$ are shown in Figure 8. Simulated LAI $I_{\max }$ was not sensitive to the change in initial values of $L_{\mathrm{g}}$ and $L_{\mathrm{s}}$ ( $40 \%$ change in these variables resulted in $0.2 \%$ change in $\mathrm{LAI}_{\max }$ ). There was a minimal sensitivity to increasing $\Delta L_{\mathrm{g} x \max }(40 \%$ increase in this variable resulted in $1.1 \%$ increase in $\left.\mathrm{LAI}_{\max }\right)$ and $\mathrm{TL}_{\mathrm{g} 0}(40 \%$ increase in this variable resulted in $1.8 \%$ decrease in $\left.\mathrm{LAI}_{\max }{ }^{\mathrm{g}}\right)$, a moderate sensitivity to change in $\Delta L_{s x \max }(a \pm 40 \%$ change in this variable resulted in $\pm 7.3 \%$ change in LAI $_{\max }$ ), and high sensitivity to decreasing $\Delta L_{\mathrm{g} x \max }(40 \%$ decrease in this variable resulted in $22.7 \%$ decrease in $\left.\mathrm{LAI}_{\max }\right)$ and $\mathrm{TL}_{\mathrm{g} 0}(40 \%$ decrease in this variable resulted in $37.1 \%$ decrease in $\mathrm{LAI}_{\max }^{\mathrm{g}}$ ).

\section{Discussion}

The first derivatives of the logistic equations described the potential rate of expansion and senescence at a given developmental stage. Such an approach of simultaneous simulation of expanding and senescing leaf area has also been used in sunflower (Chapman et al., 1993). A unique feature of the model described here is that population density attrition is accounted for, which is relatively large in soybean as compared to monocots plants such as maize and wheat (Specht et al., 2006).

The proposed model was capable of simulating LAI well under near-optimal growth conditions. When there are unknown limitations to growth such as at Mead, a pragmatic approach can be used to address these limitations. However, this pragmatic approach does not address the reasons for these limitations. To expand the applicability of this model, future research should be directed to address these limitations particularly since they appear to limit seed yield (Figure 2).

This LAI model was designed to be used with a previously developed soybean phenology model (Setiyono et al., 2007). In addition to the water balance parameters, the LAI model requires only plant population density and stem termination type as input parameters (maturity group is required for the phenology simulation). These minimum input requirements are a major advantage of this model as compared to other models (as discussed in Section 1).

Soybean phenological stages critical to the proposed model were emergence, V2, R1, and R7. Emergence was the starting point of leaf expansion. It was assumed that V2 was the starting point of postemergence reduction of PD. There was only a very minimal impact in simulated LAI when the beginning of this reduction occurred at emergence rather than at V2 (data not shown). In order to use the seed drop rate as an input instead of the PD estimated at the V2 stage, emergence survival needs to be accounted for. Rainfall and temperatures soon after sowing are potential factors that can influence emergence survival (Specht et al., 2006).

A key assumption used in the model was that temperature and water availability are the primary driving forces for leaf growth as a function of cell division and expansion. The approach used in this model is only valid when leaf growth is not source limited, which can only be achieved when agronomic management is optimized. Tardieu et al. (1999) used a similar approach to simulate leaf area in sunflower (Helianthus annus L.) and maize (Zea mays L.).

Developing mathematical relationships between variables of the logistic equations (Equations (9), (10), (15) and (16)) improved the applicability of this model by the straightforward, direct calculation of the independent variables. This results in the use of variables with clear biological meaning and/or those that can be related to readily available input parameters such as PD and stem termination type (Table 3). Considering the effect of inter-specific competition on plant growth (Buttery, 1969), assuming that maximum expansion of leaf area and maximum rate of change of expanding leaf area were negatively correlated with PD was reasonable. The relationships between maximum expanding leaf area and maximum senescing leaf area and between maximum rate of change of expanding leaf area and maximum rate of change of senescing leaf area (Table 3) explain the self destructing nature of soybean growth (Sinclair, 1986) and the often observed shading effect on senescence (Pons and Pearcy, 1994).

\section{Conclusion}

The proposed model provided a robust simulation of soybean LAI in near-optimal conditions, while requiring relatively few input vari- 
ables. Having considerably fewer requirements for cultivar-specific data was an advantage of this model, particularly for practical model applications rather than for detailed analyses of genotypic differences. To generalize the results of this study, the collection of high-quality data sets from field studies in which soybean is grown at near yield potential levels is required. Further improvements of the proposed model will be possible by incorporating specific feedback mechanisms that capture interactions of leaf development with source-driven processes (such as biomass accumulation), while maintaining realistic leaf growth and senescence processes.

\section{Acknowledgments}

Funding for this research was provided by the Nebraska Soybean Board, the International Plant Nutrition Institute (IPNI) through the Foundation for Agronomic Research (FAR) and the Fluid Fertilizer Foundation (FFF). The authors express their appreciation to Angela Bastidas, Joe Mitchell, Travis Wegner, Darren Binder, Tim Arkebauer, and student workers for their help with field operations and measurements and to Haishun Yang for his valuable comments on LAI modeling.

\section{Appendix A. Brief description of water balance simulation using a modified Campbell and Diaz (1988) model}

\section{Input parameter:}

(1) Water content $(\mathrm{v} / \mathrm{v})$ at field capacity $\left(w c_{\mathrm{fc}}\right)$, permanent wilting point $\left(w c_{\text {pwp }}\right)$, and air-dried soil $\left(w c_{\text {ad }}\right)$. For the field experiment site in Lincoln, NE: $w c_{\mathrm{fc}}=0.315, w c_{\mathrm{fc}}=0.109, w c_{\mathrm{fc}}=0.02$. For Mead, NE: $w c_{\mathrm{fc}}=0.286, w c_{\mathrm{fc}}=0.173, w c_{\mathrm{fc}}=0.02$.

(2) Maximum rooting depth $\left(\mathrm{RD}_{\max }\right)(\mathrm{m})$.

For cultivars grown in Lincoln and at Mead, $\mathrm{RD}_{\max }=1.6 \mathrm{~m}$.

\section{Assumptions:}

(1) Water potentials at field capacity $\left(\psi_{\mathrm{fc}}\right)$ and permanent wilting point $\left(\psi_{\text {pwp }}\right)$ are -30 and $-1500 \mathrm{kPa}$, respectively.

(2) Surface storage $(s)=0.1 \mathrm{~m}$. Surface storage determines the amount of runoff following a precipitation event.

(3) Maximum root water uptake $\left(E_{\max }\right)=0.01 \mathrm{~m}$.

$E_{\max }$ is used in the calculation of minimum root resistance $\left(R_{\mathrm{MIN}}\right)$

$$
R_{\mathrm{MIN}}=\frac{(2 / 3) \psi_{\mathrm{pwp}}}{E_{\max }}
$$

\section{References}

Acock and Trent, 1991 - B. Acock and A. Trent, The Soybean Crop Simulator, Glycim: Documentation for the Modular Version 91, Department of Plan, Soil, and Entomological Sciences, University of Idaho, Moscow, Idaho (1991)

Adviento-Borbe et al., 2007 - M. A. A. Adviento-Borbe, M. L. Haddix, D. L. Binder, D. T. Walters, and A. Dobermann, Soil greenhouse gas fluxes and global warming potential in four high-yielding maize systems, Global Change Biol. Postprint. (2007) doi:10.1111/j.1365-2486.2007.01421.x.

Bastidas et al., 2008 - A. M. Bastidas, T. D. Setiyono, A. Dobermann, K. G. Cassman, R. W. Elmore, G.L. Graef and J.E. Specht, Soybean sowing date- the vegetative, reproductive, and agronomic impacts, Crop Sci. 48 (2008) doi:10.2135/cropsci2006.05.0292.

Boogard et al., 1998 - Boogard, H. L., van Diepen, C. A., Rötter, R. P., Cabrera, J. M. C. A., van Laar, H.H., 1998. User's Guide for the WOFOST 7.1 Crop Growth Simulation Model and WOFOST Control Center 1.5. Technical Document 52. DLO Winand Staring Centre, Wageningen, The Netherlands.

Boote et al., 1998 - K. J. Boote, J. W. Jones, and G. Hoogenboom, Simulation of crop growth: CROPGRO model. In: R.M. Peart and R.B. Curry, Editors, Agricultural Systems Modeling and Simulation, Marcel Dekker, Inc., New York, USA (1998), pp. 651-692.

Boote et al., 2003 - K. J. Boote, J. W. Jones, G. Hoogenboom, W. D. Batchelor and C. H. Porter, CROPGRO. Plant growth and partitioning model. In: J. W. Jones, G. Hoogenboom, P. W. Wilkens, C. H. Porter and G. Y. Tsuji, Editors, Decision Support System for Agrotechnology Transfer Version 4. 0. Volume 4. DSSAT v4: Crop Model Documentation, University of Hawaii, Honolulu, Hawaii (2003), pp. 1-102.

Brisson et al., 2003 - N. Brisson, C. Gary, E. Justes, R. Roche, B. Mary, D. Ripoche, D. Zimmer, J. Sierra, P. Bertuzzi, P. Burger, F. Bussiere, Y.M. Cabidoche, P. Cellier, P. Debaeke, J. P. Gaudillere, C. Henault, F. Maraux, B. Seguin, and H. Sinoquet, An overview of the crop model STICS, Eur. J. Agron. 18 (2003), pp. 309-332.

Brisson et al., 2006 - N. Brisson, J. Wery and K. Boote, Fundamental concepts of crop models illustrated by a comparative approach. In: D. Wallach, D. Makowski and J.W. Jones, Editors, Working with Dynamic Crop Models, Elsevier, Amsterdam (2006), pp. 257-279.

Burke et al., 1984 - J.J. Burke, W. Kalt-Tores, J. Swafford, J.W. Burton and R.F. Wilson, Studies on genetic male-sterile soybeans. III. The initiation of monocarpic senescence, Plant Physiol. 75 (1984), pp. 1058-1063.

Buttery, 1969 - B.R. Buttery, Analysis of the growth of soybean as affected by plant population and fertilizer, Can. J. Plant Sci. 49 (1969), pp. 675-684.

Campbell and Diaz, 1988 - G.S. Campbell and R. Diaz, Simplified soil-water balance models to predict crop transpiration. In: F.R. Bidinger and C. Johansen, Editors, Drought Research Priorities for the Dryland Tropics, ICRISAT, Pantancheru, India (1988), pp. 15-26.

Chapman et al., 1993 - S.C. Chapman, L. Graeme, L. Hammer and H. Meinke, A sunflower simulation model: I. Model development, Agron. J. 85 (1993), pp. 725-735.

Curry et al., 1975 - R.B. Curry, C.H. Baker and J.G. Streeter, SOYMOD I: a dynamic simulator of soybean growth and development, Trans. ASAE 18 (1975), pp. 963-968.

Dardanelli et al., 1997 - J.L. Dardanelli, O.A. Bachmeier, R. Sereno and R. Gil, Rooting depth and soil water extraction patterns of different crops in a silty loam Haplustoll, Field Crop Res. 54 (1997), pp. 29-38.

Egli and Bruening, 2004 - D.B. Egli and W.P. Bruening, Water stress, photosynthesis, seed sucrose levels and seed growth in soybean, J. Agric. Sci. 142 (2004), pp. 1-8.

Fehr and Caviness, 1977 - W.R. Fehr and C.E. Caviness, Stages of Soybean Development. Cooperative Extension Service, Agriculture and Home Economics Experiment Station, Iowa State University, Ames, Iowa (1977).

Frederick et al., 1991 - J.R. Frederick, J.T. Wooley, J.D. Hesketh and D.B. Peters, Seed yield and agronomic traits of old and modern soybean cultivars under irrigation and soil water-deficit, Field Crop Res. 27 (1991), pp. $71-82$. 
Gepstein, 2004 - S. Gepstein, Leaf senescence - not just a 'wear and tear' phenomenon, Genome Biol. 5 (2004), pp. 212.1-212.3.

Grant et al., 2007 - R.F. Grant, T.J. Arkebauer, A. Dobermann, K.G. Hubbard, T.T. Schimelfenig, A.E. Suyker, S.B. Verma and D.T. Walters, Net biome productivity of irrigated and rainfed maize soybean rotations: modeling vs. measurements, Agron. J. 99 (2007), pp. 1404-1423.

Gunn et al., 1999 - S. Gunn, J.F. Farrar, B.E. Collis and M. Nason, Specific leaf weight in barley: individual leaves versus whole plants, New Phytol. 413 (1999), pp. 45-51.

Guo et al., 2004 - Y. Guo, Z. Cai and S. Gan, Transcriptome of Arabidopsis leaf senescence, Plant Cell Environ. 27 (2004), pp. 521-549.

Hesketh et al., 1973 - J.D. Hesketh, D.L. Myhre and C.R. Willey, Temperature control of time intervals between vegetative and reproductive events in soybeans, Crop Sci. 13 (1973), pp. 250-254.

Hyams, 2001 - D. Hyams, Curve Expert 1.3. A Comprehensive Curve Fitting System for Windows, Hixson, TN (2001).

Lieth et al., 1986 - J.H. Lieth, J.F. Reynolds and H.H. Rogers, Estimation of leaf area of soybeans grown under elevated carbon dioxide, Field Crop. Res. 13 (1986), pp. 193-203.

Lugg and Sinclair, 1979 - D.G. Lugg and T.R. Sinclair, A survey of soybean cultivars for variability in specific leaf weight, Crop. Sci. 19 (1979), pp. 887-892.

Mayaki et al., 1976 - W.C. Mayaki, I.D. Teare and L.R. Stone, Top and root growth of irrigated and nonirrigated soybeans, Crop Sci. 16 (1976), pp. 92-94.

Milthorpe and Moorby, 1979 - F.L. Milthorpe and J. Moorby, An Introduction to Crop Physiology, Cambridge University Press, New York (1979).

Muchow, 1985 - R.C. Muchow, Canopy development in grain legumes grown under different soil water regimes in a semi-arid tropical environment, Field Crop. Res. 11 (1985), pp. 99-109.

Pons and Pearcy, 1994 - T.L. Pons and R.W. Pearcy, Nitrogen reallocation and photosynthetic acclimation in response to partial shading in soybean plants, Physiol. Plant. 92 (1994), pp. 636-644.

Potter and Jones, 1977 - J.R. Potter and J.W. Jones, Leaf area partitioning as an important factor in growth, Plant Physiol. 59 (1977), pp. 10-14.

Reicosky and Heatherly, 1990 - D.C. Reicosky and L.G. Heatherly, Soybean. In: B.A. Stewart and D.R. Nielsen, Editors, Irrigation of Agricultural Crops, ASA, CSSA, SSSA, Madison, WI (1990), pp. 639-675.

Ripoche, 1999 - D. Ripoche, User's Guide WINSTICS, INRA, Avignon (1999).

Robertson et al., 2002 - M.J. Robertson, P.S. Carberry, N.I. Huth, J.E. Turpin, M.E. Probert, P.L. Poulton, M. Bell, G.C. Wright, S.J. Yeates and R.B. Brinsmead, Simulation of growth and development of diverse legume species in APSIM, Aust. J. Agric. Res. 53 (2002), pp. 429-446.

SAS Institute, 1999 - SAS Institute. The SAS System for Windows. Release 8.02. 1999. SAS Institute, Cary, NC (Ref Type: Computer Program).

Setiyono et al., 2007 - T.D. Setiyono, A. Weiss, J. Specht, A.M. Bastidas, K.G. Cassman and A. Dobermann, Understanding and modeling the effect of temperature and daylength on soybean phenology under high-yield conditions, Field Crop. Res. 100 (2007), pp. 257-271.
Sinclair, 1986 - T.R. Sinclair, Water and nitrogen limitation in soybean grain production. I. Model development, Field Crop Res. 15 (1986), pp. $125-141$.

Sinclair and Ludlow, 1986 - T.R. Sinclair and M.M. Ludlow, Influence of soil water supply on plant water balance of four tropical grain legumes, Aust. J. Plant Physiol. 13 (1986), pp. 329-341.

Specht et al., 1986 - J.E. Specht, J.H. Williams and C.J. Weidenbenner, Differential responses of soybean genotypes subjected to a seasonal soil water gradients, Crop Sci. 26 (1986), pp. 922-934.

Specht et al., 2006 - J.E. Specht, A. Bastidas, F. Salvagiotti, S. Shanmugasundaram, A.J. Liska, A. Dobermann, D.T. Walters and K.G. Cassman, Soybean yield potential and management practices required to achieve it. In: L.S. Murphy, Editor, Proceedings of the 2006 Fluid Forum, vol. 23 Fluid Fertilizer Foundation, Manhattan, KS (2006) [CD-ROM].

Stewart et al., 1976 - B.A. Stewart, D.A. Woolhiser, W.H. Wischemeier, J.H. Caro and M.H. Frere, Control of Water Pollution from Cropland. An Overview vol. 2, U.S. Department of Agriculture, Agricultural Research Service, Beltsville, MD (1976).

Supit and Van der Groot, 2003 - I. Supit and E. Van der Groot, Updated System Description of the WOFOST Crop Growth Simulation Model as Implemented in the Crop Growth Monitoring System, CGMS, Applied by the European Commission, Treemail Publisher, Heelsum, The Netherlands (2003).

Tardieu et al., 1999 - F. Tardieu, C. Granier and B. Muller, Research review. Modeling leaf expansion in a fluctuating environment: are changes in specific leaf area a consequence of changes in expansion rate?, New Phytol. 143 (1999), pp. 33-43.

Tardieu et al., 2005 - F. Tardieu, M. Reymond, B. Muller, T. Simonneau, W. Sadok and C. Welcker, Linking physiological and genetic analyses of the control of leaf growth under changing environmental conditions, Aust. J. Agric. Res. 56 (2005), pp. 937-946.

Verma et al., 2005 - S.B. Verma, A. Dobermann, K.G. Cassman, D.T. Walters, J.M.H. Knops, T.J. Arkebauer, A.E. Suyker, G.G. Burba, B. Amos, H.S. Yang, D. Ginting, K.G. Hubbard, A.A. Gitelson and E.A. WalterShea, Annual carbon dioxide exchange in irrigated and rainfed maize-based agroecosystems, Agric. Forest Meteorol. 131 (2005), pp. 77-96.

Wang and Engel, 1998 - E. Wang and T. Engel, Simulation of phenological development of wheat crops, Agric. Syst. 58 (1998), pp. 1-24.

Wang et al., 2003 - F. Wang, C.W. Fraisse, N.R. Kitchen and K.A. Sudduth, Site specific evaluation of the CROPGRO-soybean model on Missouri claypan soils, Agric. Syst. 76 (2003), pp. 985-1005.

Wilkerson et al., 1983 - G.G. Wilkerson, J.W. Jones, K.J. Boote, K.T. Ingram and J.W. Mishoe, Modeling soybean growth for crop management, Trans. ASAE 26 (1983), pp. 63-73.

Wright et al., 1999 - S.R. Wright, C.D. Raper Jr. and T.W. Rufty Jr., Comparative response of soybean (Glycine max), sicklepod (Senna obstusifolia), and Palmer amaranth (Amaranthus palmeri) to root zone and aerial temperatures, Weed Sci. 47 (1999), pp. 167-174. 